ISSN 2078-6441. Вісник Львівського університету. Серія географічна. 2018. Випуск 52. С. 61-71.

Visnyk of the Lviv University. Series Geography. 2018. Issue 52. P. 61-71.

http:/ / dx.doi.org/10.30970/vgg.2018.52.10169

911.3:338.483.1(477.85)

\author{
: \\ еронік рицку \\ ернівецький н ціон льний університет імені рія едькович, \\ вул. оцюбинського, 2, 58012, ернівці, кр їн , \\ e-mail: veronika-hrytsku@ukr.net
}

иявлено основні умови й ресурси формув ння т розвитку туристичної діяльності в ернівецькій обл. як тр нскордонному регіоні. собливу ув гу приділено суспільно-геогр фічній оцінці й ді гностиці сприятливих і несприятливих чинників, т кож т ких, які визн ч ють функціон льно-г лузеву структуру й територі льну орг ніз цію туристичної діяльності. к сукупність чинників виділено суспільно-геогр фічне положення (тр нскордонне положення); поселенську мережу, демовідтворюв льну ситу цію і з йнятість н селення; рівень господ рського розвитку; потенці л н д ння туристичних послуг. пок зником щільності н селення ернівецьк обл. посід є четверте місце в кр їні, і цей пок зник більший н $38,1 \%$ від середньоукр їнського. йбільш $з$ селеними є рівнинні т передгірські р йони. итловий фонд обл сті дост тній і відповід $є$ н ціон льному рівню $-22,1 \mathrm{~m}^{2} / \mathrm{H}$ одного жителя, ліпше умов ми прожив ння з безпечені сільські жителі (23,4 м²/особу), ніж міські (20,2 м²/особу). обл сті н явн зн чн довжин т досить розг лужен мереж шляхів сполучення. е сприяє інтенсивності перевезень, тов рообміну, з безпеченню споживчого ринку, збільшенню можливостей тр нсферу туристів. роте ост нніми рок ми шляхове будівництво ведуть н 6 г то нижчими темп ми, ніж у попередні періоди. жливе зн чення в 3 йнятості н селення туристичною діяльністю м є робот освітніх, медичних, культурно-мистецьких з кл дів. ет льно про н лізов но функціонув ння соці льної інфр структури обл сті. уковинський тр нскордонний регіон м $€$ б г то структурних компонентів рекре ційних ресурсів, $€$ регіоном б г топрофільного літнього, зимового, гірсько-спортивного, м сового пізн в льно-оздоровчого відпочинку. икорист ння ст тистичних методів т кількісних пок зників д ло змогу виявити особливості й специфіку туристичної діяльності, обгрунтув ти перспективи вдоскон лення орг ніз ції, структури й з безпечення ст лого розвитку.

лючові слов : туристичн діяльність, тр нскордонний регіон, ресурси, н селення, 3 йнятість, ст лий розвиток, перспективи.

ормув ння т розвиток туристичної діяльності в тр нскордонному регіоні, до якого н лежить ернівецьк обл., відбув ється під впливом сукупності суспільногеогр фічних умов, ресурсів бо чинників, що м ють як з г льнон ціон льні, т к і суто регіон льні прояви. лежно від скл ду т сукупної дії цих чинників з леж ть туристичні дестин ції, спеці ліз ція й н прями туристичної діяльності, іiї сезонність, т кож ефективність т перспективи розвитку. е зумовлює теоретичну й пр ктичну зн чимість обр ного н пряму досліджень.

(C) рицку ., 2018 
особливу ув гу в ході вивчення умов т ресурсів формув ння й розвитку туристичної діяльності у ернівецькій обл. як тр нскордонному регіоні з слуговують с ме специфічні, регіон льні чинники. кщо н логічні дослідження н були зн чного поширення н рівні кр їни й н ведені у пр цях • ейдик [1], • юбіцевої [4], . лійник [5], . м ля [7], . теченк [9], . опчієв [10] т інших відомих н уковців, то щодо ернівецької обл. вони потребують под льшого поглиблення. кту льними є суспільно-геогр фічн оцінк й ді гностик сприятливих і несприятливих чинників, т кож т ких, які визн ч ють функціон льно-г лузеву структуру й територі льну орг ніз цію туристичної діяльності.

огляду н це $н$ mem - виявити суспільно-геогр фічні чинники формув ння т розвитку туристичної діяльності у ернівецькій обл. як тр нскордонному регіоні й обгрунтув ти н прями іiї вдоскон лення з ур хув нням можливостей тр нскордонного співробітництв .

ля досягнення цієї мети необхідно викон ти т кі з вд ння:

- визн чити суспільно-геогр фічне положення уковинського ( ернівецького) тр нскордонного регіону;

- сх р ктеризув ти поселенську мережу, демовідтворюв льну ситу цію й з йнятість н селення ернівецької обл.;

- про н лізув ти рівень господ рського розвитку т регіон льної інфр структури регіону;

- оцінити потенці л н д ння туристичних послуг т обгрунтув ти перспективи вдоскон лення орг ніз ції, структури й з безпечення ст лого розвитку в тр нскордонному регіоні.

уристичн діяльність, м ючи чітко вир жену геогр фічну зумовленість, потребує всебічної оцінки її проявів у вигляді н явних бо потенційних умов т ресурсів.

н шу думку, у ернівецькій обл. до геогр фічних передумов розвитку туризму необхідно віднести: тр нскордонне положення, суспільний (соці льно-економічний) т природний ресурсний потенці л регіону. р нскордонне положення м є подвійне н в нт ження [1, с. 43]. скільки обл сть межує з європейськими кр їн ми, то може впров джув ти передовий європейський досвід. іншого боку, вон є своєрідним форпостом, першою зустріч $є$ іноземних подорожніх т формує перше вр ження про кр їну. е спонук є до більшої відповід льності щодо розвитку всіх видів діяльності, p ціон льного природокористув ння т естетики в орг ніз ції території.

успільно-геогр фічний блок чинників туристичної діяльності утворюють поселенськ мереж й демовідтворюв льн ситу ція, рівень економічного розвитку й регіон льн інфр структур , н явність відповідних тр кцій і послуг, рівень з йнятості і життя н селення [4, с. 395]. зн чимо, що н 1 січня 2016 р. у ернівецькій обл. прожив ло 908,1 тис. осіб. ільність н селення є однією з н йбільших у кр їні і в середньому по обл сті досяг є 112,0 осіб/км ${ }^{2}$, ч стк міського н селення одн 3 н йменших у його структурі - 41,7 (див. т бл. 1).

пок зником щільності н селення ернівецьк обл. посід є четверте місце в кр їні після онецької, ьвівської т ніпропетровської обл стей. ей пок зник більший н 38,1 \% від середнього, що поряд із високою ч сткою сільських жителів (н 10,5\% більше від середньої) у з г льній структурі н селення д є змогу розвив ти всі види туристичної діяльності, н с мперед, сільський зелений туризм. е особливо кту льно в умов х н длишку трудових ресурсів через згорт ння б г тьох видів діяльності т 
Умови та ресурси формування й розвитку туристичної діяльності ...

пошук роботи 3 кордоном. о особливостей ернівецької обл. н лежить і те, що вон одн 3 неб г тьох в кр їні, де простежуються зн чні відмінності у кількості н селення, його щільності, людності н селених пунктів по дміністр тивних р йон х н дуже комп ктній території.

ількість т структур н селення ернівецької обл. н поч ток року, тис. осіб

Number and structure of population of Chernivtsi region at the beginning of the year, in thousands of people

\begin{tabular}{|c|c|c|c|c|c|}
\hline \multirow{2}{*}{ ік } & \multirow{2}{*}{$\begin{array}{c}\text { ількість } \\
\text { нелення }\end{array}$} & \multicolumn{2}{|c|}{ тому числі } & \multicolumn{2}{c|}{$\begin{array}{c}\text { відсотк х до всього } \\
\text { нслення }\end{array}$} \\
\cline { 3 - 6 } & & міське & сільське & міське & сільське \\
\hline 1939 & 812,3 & 166,4 & 645,9 & 20,5 & 79,5 \\
\hline 1959 & 774,1 & 203,0 & 571,1 & 26,2 & 73,8 \\
\hline 1979 & 889,8 & 337,1 & 552,7 & 37,9 & 62,1 \\
\hline 1991 & 938,6 & 398,8 & 539,8 & 42,5 & 57,9 \\
\hline 1999 & 935,4 & 399,3 & 536,1 & 42,7 & 57,3 \\
\hline 2005 & 911,5 & 372,6 & 538,9 & 40,9 & 59,1 \\
\hline 2016 & 908,1 & 391,1 & 517,0 & 41,7 & 58,3 \\
\hline
\end{tabular}

кл дено з д ними т тистичного щорічник ернівецької обл., 2017 p.

йбільш з селені рівнинні т передгірські р йони - торожинецький, овоселицький, іцм нський, либоцький, отинський, де прожив є, відповідно, 100,3, 77,8, 68,8, 74,1, 64,2 тис. осіб, бо 385,2 тис. (87,4 \%) сільських мешк нців. йменш кількість н селення х р ктерн для гірського утильського р-ну $(26,4$ тис. осіб) т н йменшого в обл сті ерц ївського р-ну (33,1 тис. осіб н площі лише 0,31 тис. км²). утильському р-ні н йменш щільність н селення - 28,8 осіб/км². Г лом цей пок зник м $є$ зн чну мплітуду й відрізняється по обл сті м йже у 2,1 p 3 , що необхідно вр ховув ти у пл нув нні й прогнозув нні туристичної діяльності.

о р йонів зі щільністю 62,9-65,5 осіб/км² н леж ть ижницький т ельменецький; 83,1-92,8 осіб/км² прожив є у торожинецькому, ст внівському, окирянському, отинському р йон х; 104,7-116,1 - у ерц ївському, либоцькому, овоселицькому, іцм нському. ст тевій структурі н селення протягом ост ннього сторіччя перев ж ють жінки. ост нні п’ять років вони ст новили 54,0 \% у структурі н селення, чоловіки - 46,0 \%. исок ч стк н селення у пр цезд тному віці $-59,9 \%$, т кож н селення, яке ст рше пр цезд тного - 21,7\%. е свідчить, що пр ктично кожен п’ятий житель обл сті є пенсіонером, в ст внівському, іцм нському, овоселицькому - кожен четвертий. к ситу ція скл л ся вн слідок ст ріння н селення т зменшення його природного приросту впродовж ост ннього десятиріччя.

1995 р. природний приріст н селення уковини ст в від'ємним. кщо у 1990 р. коефіцієнт природного приросту дорівнюв в 3,8 осіб/1000 осіб, то 1995 р. він ст новив -0,2, 2009 - -1,3 осіб/1000 осіб. ого зниження відбув ється вн слідок різкого скорочення н роджув ності н віть 3 зменшення смертності. прикл д, коефіцієнт н роджув ності зменшився з 14,9 осіб/1000 осіб у 1990 р. до 11,1 осіб/1000 осіб у 2016 р. собливо різко скоротил ся н роджув ність у міст х. е свідчить про депопуляцію 
місцевого н селення т спонук є до підвищення якості його життєдіяльності, повернення до родинних цінностей і тр дицій.

итловий фонд у ернівецькій обл. є дост тнім. безпеченість житлом у середньому н одного жителя зн чн і відповід $є$ н ціон льному рівню $-22,1 \mathrm{~m}^{2}$. одноч с житловий фонд неухильно зрост є і досяг є у міст х $20,2 \mathrm{~m}^{2} / \mathrm{H}$ одного жителя, у сел $\mathrm{x}-23,4 \mathrm{M}^{2}$. дн к 3 безпеченість житлового фонду водопровідними т к н ліз ційними мереж ми, центр льним оп ленням, г зом, г рячим водопост ч нням н 20-30\% менш, ніж у середньому по кр їні (т бл. 2). е пояснюють не стільки нижчим рівнем бл гоустрою сільських н селених пунктів, з вдяки яким зрост є житлове будівництво, скільки орієнт цією н іннов ційні енерго- т ресурсозбережні технології, які м ють, перев жно, індивіду льний х р ктер й орієнтуються н потреби букв льно кожного жителя в теплі, воді, освітленні тощо [9, с. 69].

блиия 2

ин мік житлового фонду ернівецької обл., тис. м² 3 г льної площі

Dynamics of the housing stock of Chernivtsi region, thousands $\mathrm{m}^{2}$ of the total area

\begin{tabular}{|l|c|c|c|c|}
\hline \multirow{2}{*}{ ок зник } & \multicolumn{3}{|c|}{ ок и } & ідсоток \\
\cline { 2 - 4 } & $\mathbf{1 9 9 0}$ & $\mathbf{2 0 0 5}$ & $\mathbf{2 0 1 6}$ & $\mathbf{2 0 1 6 / 1 9 9 0}$ \\
\hline есь житловий фонд & 16462 & 19431 & 22337 & $+35,7$ \\
\hline середньому н одного жителя, ${ }^{2}$ & 17,5 & 21,3 & 24,7 & $+58,3$ \\
\hline іський житловий фонд & 6314 & 7380 & 8591 & $+36,1$ \\
\hline середньому н одного міського жителя, м ${ }^{2}$ & 15,9 & 19,8 & 22,2 & $+39,6$ \\
\hline ільський житловий фонд & 10148 & 12122 & 13746 & $+35,5$ \\
\hline середньому н одного сільського жителя, м $^{2}$ & 18,7 & 22,4 & 26,5 & $+41,7$ \\
\hline
\end{tabular}

кл дено з д ними т тистичного щорічник ернівецької обл., 2017 p.

т бл. 2 чимо, що поступово з безпечення житлом н одного жителя зрост $є$. ей пок зник збільшується як у міст х, т к і в сел х. езумовно, т к дин мік сприяє розвитку сільського зеленого туризму, проте для ре льної ситу ції потрібно про н лізув ти т кож пок зники розвитку комун льної сфери сільських територій [7, с. 34]. уттєвим є й пит ння про з безпечення т н явність житлового фонду окремо по кожному р йону обл сті (т бл. 3). ого оцінк д є змогу виявити ліпші умови розміщення подорожніх в екологічному, сільському зеленому, спортивному гірському туризмі.

ні т бл. 3 з свідчують поступове збільшення житлового фонду н селення, особливо в сільських $\mathrm{p}$ йон х. н шу думку, це пов'яз не з поступовим підвищенням рівня доходів місцевого н селення. ніше ф хівці вже з зн ч ли про фін нсові н дходження 3-3 кордону від мігр нтів, які є інвестор ми в економіку рідного кр ю [3, с. 234]. ерев жн більшість цих коштів н дходить у будівництво житл й споруд виробничого призн чення - готелів, рестор нів, м г зинів тощо. ля туристичної діяльності цей чинник сприятливий тим, що перев жну більшість будівель споруджують з усім побутовими зручностями (т бл. 4), поліпшують їхній зовнішній вигляд, от молодь поступово переселяється в міст, звільняючи житлову площу. $\mathrm{K}$ мігр ція н селення не корисн для сільської економіки, відтворення сільських територій з г лом, проте для туристичної діяльності вон $є$ дост тньо нейтр льним чинником. 
Умови та ресурси формування й розвитку туристичної діяльності ...

ериторі льн структур й дин мік житлового фонду ернівецької обл., тис. м $^{2}$ г льної площі

Territorial structure and dynamics of the housing stock of Chernivtsi region, thousands $\mathrm{m}^{2}$ of the total area

\begin{tabular}{|c|c|c|c|c|c|c|}
\hline \multirow{2}{*}{ йон, місто } & \multicolumn{5}{|c|}{ оки } & \multirow{2}{*}{$\begin{array}{r}\text { ідсоток } \\
2016 / 1990\end{array}$} \\
\hline & 1990 & 1995 & 2000 & 2005 & 2016 & \\
\hline ернівецьк обл. & 16462 & 17852 & 18788 & 19431 & 22337 & $+35,7$ \\
\hline ернівці & 4159 & 4502 & 4616 & 4843 & 5586 & $+34,3$ \\
\hline оводністровськ & & & 218 & 226 & 225 & - \\
\hline ижницький & 971 & 1050 & 1204 & 1237 & 1488 & $+53,2$ \\
\hline ерц ївський & & 511 & 545 & 576 & 754 & - \\
\hline либоцький & 1555 & 1259 & 1350 & 1446 & 1826 & $+17,4$ \\
\hline ст внівський & 1031 & 1103 & 1203 & 1292 & 1413 & $+37,0$ \\
\hline ельменецький & 1020 & 1073 & 1160 & 1172 & 1180 & $+11,5$ \\
\hline іцМ нсьКИй & 1334 & 1709 & 1751 & 1817 & 2042 & $+53,0$ \\
\hline овоселицький & 1614 & 1725 & 1870 & 1897 & 2153 & $+33,4$ \\
\hline утильський & 419 & 446 & 509 & 526 & 583 & $+39,1$ \\
\hline окирянський & 1278 & 1281 & 1110 & 1079 & 1101 & $-13,8$ \\
\hline торожинецький & 1374 & 1557 & 1640 & 1704 & 2304 & $+67,7$ \\
\hline отинський & 1532 & 1613 & 1612 & 1616 & 1682 & $+9,8$ \\
\hline
\end{tabular}

кл дено з д ними т тистичного щорічник ернівецької обл., 2017 p.

блиия 4

труктур т дин мік комун льного обл дн ння житл у ернівецькій обл сті, \% Structure and dynamics of housing equipment in Chernivtsi region, \%

\begin{tabular}{|c|c|c|c|c|c|c|c|c|}
\hline \multirow{3}{*}{ ок зник обл дн ння } & \multicolumn{6}{|c|}{ оки } & \multirow{2}{*}{\multicolumn{2}{|c|}{$\begin{array}{c}\text { ідсоток } \\
2016 / 1995 \\
\end{array}$}} \\
\hline & \multicolumn{2}{|c|}{1995} & \multicolumn{2}{|c|}{2005} & \multicolumn{2}{|c|}{2016} & & \\
\hline & мicт & сел & мicт & сел & мicт & сел & мicт & сел \\
\hline одогін & 50,2 & 2,0 & 58,5 & 5,3 & 62,8 & 37,5 & $+25,1$ & $+1775,0$ \\
\hline н ліз ція & 50,0 & 1,6 & 58,5 & 5,0 & 62,6 & 37,4 & $+25,2$ & $+2237,5$ \\
\hline п лення & 39,4 & 1,5 & 55,7 & 8,1 & 62,5 & 51,6 & $+58,6$ & $+993,3$ \\
\hline $30 \mathrm{M}$ & 77,3 & 80,7 & 94,0 & 79,3 & 91,1 & 86,5 & $+17,8$ & $+7,1$ \\
\hline ряче водопост ч ння & 30,7 & 0,3 & 37,8 & 2,1 & 50,6 & 35,1 & $+64,8$ & +11600 \\
\hline $\mathrm{HH}$ & 46,3 & 1,4 & 51,4 & 3,7 & 52,4 & 9,1 & $+13,1$ & +650 \\
\hline ідлогові електроплити & 1,9 & 0,2 & 1,1 & 0,1 & 1,0 & 0,1 & $-52,6$ & -50 \\
\hline
\end{tabular}

кл дено з д ними т тистичного щорічник ернівецької обл., 2017 p.

т бл. 4 б чимо, що існує зн чний приріст інженерного обл штув ння житлового фонду в обл сті порівняно з 1995 p. к перспектив д $є$ підст ви сподів тися, що к н ліз ція, г ряче водопост ч ння не будуть перепоною в н д нні послуг турист м у місцях розміщення. жливим є т кож бл гоустрій н селених пунктів як своєрідн туристичн тр кція, дже рхітектурно-будівельні тр диції кр ю с мобутні порівняно з іншими регіон ми (див. т бл. 5). 
л гоустрій н селених пунктів ернівецької обл. Improvement of settlements of Chernivtsi region

\begin{tabular}{|c|c|c|c|c|}
\hline \multirow{2}{*}{ селені пункти } & \multicolumn{3}{|c|}{ ок И } & \multirow{2}{*}{$\begin{array}{r}\text { ідсоток } \\
2016 / 1995 \\
\end{array}$} \\
\hline & 1995 & 2005 & 2016 & \\
\hline \multicolumn{5}{|c|}{ ють водопровід } \\
\hline іст & 11 & 11 & 11 & 0 \\
\hline елищ міського типу & 8 & 8 & 8 & 0 \\
\hline ільські н селені пункти & 12 & 10 & 8 & $-33,3$ \\
\hline \multicolumn{5}{|c|}{ ють к н ліз иію } \\
\hline ict & 9 & 9 & 9 & 0 \\
\hline елищ міського типу & 8 & 8 & 8 & 0 \\
\hline ільські н селені пункти & 11 & 9 & 10 & $-9,09$ \\
\hline \multicolumn{5}{|c|}{ зифіков ні тільки природним і природним зрідженим г зом } \\
\hline ict & 11 & 11 & 11 & 0 \\
\hline елищ міського типу & 8 & 8 & 8 & 0 \\
\hline ільські н селені пункти & 398 & 389 & 389 & $-2,2$ \\
\hline \multicolumn{5}{|c|}{ зифіков ні тільки зрідженим г зом } \\
\hline ict & 2 & 1 & 1 & -50 \\
\hline елищ міського типу & 4 & 3 & 2 & -50 \\
\hline ільські н селені пункти & 372 & 256 & 176 & $-52,7$ \\
\hline
\end{tabular}

кл дено з д ними т тистичного щорічник ернівецької обл., 2017 p.

ротягом н лізов ного періоду відбул ся реструктуриз ція деяких видів п лив . прикл д, сел зі зрідженого г зу перейшли н 3 стосув ння природного г зу, пізніше - деревних т інших видів пелет. т бл. 5 відобр жено лише кількість сіл і 3 деякими позиціями пок зники, з якими бл гоустрій зменшується. дн к це зменшення пов'яз не з дміністр тивними змін ми щодо збільшення людності сільських н селених пунктів, впров дження іннов цій, т кож з диверсифік цією діяльності, про що вже з зн ч лося. иту ція в сфері обл штув ння сільських поселень, особливо диз йн сільських територій, є унік льною щодо збереження втохтонних тр дицій будівництв й рхітектури т їхнього поєдн ння з суч сними нововведеннями в експлу т ції.

ернівецькій обл. зн чн довжин т досить розг лужен мереж шляхів сполучення. е сприяє інтенсивності перевезень, тов рообміну, з безпеченню споживчого ринку, збільшенню можливостей тр нсферу туристів. роте ост нніми рок ми шляхове будівництво ведуть н б г то нижчими темп ми, ніж у попередні періоди. н чну кількість втошляхів зіпсов но вн слідок повеней 2008-2010 pp. ільність експлу т ційної довжини з лізничних колій з г льного користув ння н віть дещо знизил сь і 2016 р. ст новил 51,0 км/1 тис. км² території, бо у 1,3 р зів більше, ніж у середньому по кр їні (38,0 км/км² території). довжиною з лізниць кр їн посід є третє місце в вропі, зн чно поступ ючись 3 їхньою щільністю бг тьом кр їн м. ведення в експлу т цію 2015 р. швидкісного поїзд нтерсіті сполученням ернівці- ьвівовель ст ло зн чним чинником ктивіз ції п с жиропотоків, пожв влення туристичної діяльності, н ближення сусідньої ольщі т ілорусі до румунсько-молдовських кордонів, посиливши тр нскордонне зн чення уковинського регіону. 
Умови та ресурси формування й розвитку туристичної діяльності ...

кож вищою від середньодерж вного пок зник бул щільність втошляхів 356,0 км/тис. км² території проти 280,1 км/тис. кM$^{2}$. дн к це менше, ніж у сусідніх кр їн х - умунії (834,0 км) т олдові (374,7 км) [2]. ільше ніж удвічі зросл кількість втомобілів у прив тній вл сності н селення 2016 р. порівняно з 1990 р. кщо у 1990 р. один втомобіль прип д в н 20 жителів обл сті, то у 2016 р. - вже н кожні п’ять осіб. г лом це відповід є 3 г льнон ціон льній тенденції зрост ння втомобіліз ції н селення й сприяє розвитку туризму т якості туристичних послуг. роте для досягнення європейських ст нд ртів є зн чні можливості для розвитку.

жливу роль у розвитку туристичної діяльності, підвищенні рівня престижності життя в кр їні, з безпеченні ефективного використ ння робочого т вільного ч су відігр є інфр структурне обл штув ння н селених пунктів. бсяг його ре лізов них послуг по міст х і р йон х ернівецької обл. лише з період з 2005 по 2016 рр. збільшився м йже вдвічі. е свідчить про інтенсивне зрост ння цієї сфери в життєдіяльності н селення кр ю.

блиия 6

бсяги т дин мік діяльності підприємств сфери послуг у ернівецькій обл., тис. грн. Volume and dynamics of enterprises of services in the Chernivtsi region, thousands UAH

\begin{tabular}{|c|c|c|c|c|c|c|}
\hline \multirow[b]{2}{*}{ йон, місто } & \multicolumn{6}{|c|}{ оки } \\
\hline & 2002 & 2005 & 2010 & 2013 & 2016 & \begin{tabular}{|l}
\multicolumn{2}{|c|}{ ідсоток до } \\
3 Г льних \\
пок $3 н и к і в$
\end{tabular} \\
\hline ернівецьк обл. & 391676 & 641744 & 778476 & 1009687 & 1206501 & 100 \\
\hline ернівці & 364314 & 582201 & 727502 & 931180 & 1103873 & 91,0 \\
\hline оводністровськ & 1824 & 4261 & 7477 & 8931 & 12586 & 1,1 \\
\hline иЖницьКИй & 3436 & 5881 & 5318 & 6248 & 7006 & 0,6 \\
\hline ерц ївський & 682 & 1420 & 546 & 1018 & 2201 & 0,3 \\
\hline либоцький & 1933 & 7366 & 5669 & 6558 & 8259 & 0,7 \\
\hline ст внівський & 1772 & 2951 & 1295 & 2187 & 2877 & 0,2 \\
\hline ельменецький & 1831 & 3189 & 1694 & 2247 & 3514 & 0,3 \\
\hline іцм нський & 4414 & 12012 & 13592 & 13768 & 13555 & 1,1 \\
\hline овоселицький & 3450 & 5918 & 4587 & 7796 & 6380 & 0,6 \\
\hline утильський & 1147 & 1554 & 598 & 1252 & 1416 & 0,2 \\
\hline окирянський & 1606 & 2703 & 1368 & 2249 & 3436 & 0,3 \\
\hline торожинецький & 3456 & 7803 & 5213 & 8064 & 9840 & 0,8 \\
\hline отинський & 1811 & 4485 & 3617 & 18189 & 31558 & 2,6 \\
\hline
\end{tabular}

кл дено з д ними т тистичного щорічник ернівецької обл., 2017 p.

йбільшу кількість послуг у грошовому вимірі н д ють у м. ернівці (91,0 \% від з г льного обсягу). ей пок зник суттєво відрізняється по р йон х обл сті. йбільші його зн чення х $\mathrm{p}$ ктерні для отинського т іцм нського $\mathrm{p}$ йонів. ірш ситу ція скл л ся в утильському $\mathrm{T}$ ст внівському р йон х. ерівномірний розподіл н йв гоміших послуг по р йон х обл сті з огляду н з безпечення життєдіяльності н селення т розвитку сільського туризму нег тивно позн ч ється н продуктивності пр ці з г лом через дод ткові витр ти ч су н послуги, які можн 3 мовити $з$ помірну пл ту в р йонному центрі, не витр ч ти ч с н поїздку в обл сний центр. 
жливе зн чення в 3 йнятості сільського н селення підприємницькою діяльністю, зокрем, туристичною, м є робот освітніх, медичних, культурно-мистецьких 3 кл дів. ількість 3 кл дів дошкільного вихов ння з г лом по обл сті зросл з 309 у 2005 р. до 379 у 2016 р., тобто н 22,7 \%, в сільській місцевості - з 220 у 2005 р. до 285 у 2016 р., тобто н 29,5\%. більшення кількості дошкільних з кл дів по р йон х відповід є ст ну природного руху н селення т норм тивним з с д м їхнього пл нув ння н 3 с д $\mathrm{x}$ децентр ліз ції вл ди й дміністр тивно-територі льної реформи. прикл д, кількість дошкільних з кл дів у ерц ївському р йоні збільшил ся н 9, либоцькому - н 11 , іцм нському т овоселицькому $-\mathrm{H} 7$, торожинецькому $-\mathrm{H} \quad 12$, де в ост нні десять років поліпшил ся демогр фічн ситу ція, отже, виникл потреб в подібних з кл д х. меншення дошкільних н вч льних 3 кл дів 3 фіксов но в ельменецькому p йоні (н 4), у якому демогр фічн ситу ція погіршується.

ернівецькій обл. функціонує 428 з г льноосвітніх н вч льних 3 кл дів, що н 26 менше порівняно з 2005 p. них н вч ється 98600 учнів, бо 11,8\% усього н селення кр ю. чнів н вч ють 12000 учителів, кількість яких зменшил сь н 200 осіб порівняно з 2005 р., коли учнів було 120700 осіб. тже, зменшення кількості учителів відбув ється п р лельно зі зменшенням кількості учнів, що з г лом відобр ж є ст н демогр фічної ситу ції кр ю і всієї кр їни.

ля стр хув ння здоров'я туристів під ч с їхнього перебув ння в обл сті, т кож підвищення рівня життя н селення, відтворення трудових ресурсів в жливе зн чення м є рівень медичного обслуговув ння. зн чимо, що кількість лік рів усіх спеці ліз цій по міст х і р йон х ернівецької обл. в розр хунку н 10000 жителів 3 період 3 2005 по 2016 рр. зросл з 54,0 до 59,4 осіб, бо н $10 \%$. йвищий пок зник кількості лік рів н 10000 жителів у 2016 р. м є м. ернівці, с ме: 161,6 осіб, що н 19,8 осіб, бо н 12,2 \% більше, ніж у 2005 р. одноч с простежується зн чн диференці ція в з безпеченості лік рями, середнім медичним персон лом між м. ернівці т всім іншими міст ми й дміністр тивними р йон ми. ізниця досяг є п'яти-дев'яти р зів. іпш ситу ція із з безпеченням лік рями у ижницькому т отинському $\mathrm{p}$ йон $\mathrm{x}$, гірш - у ерц ївському т утильському.

им ле зн чення як туристичні тр кції м ють спортивні споруди. 2016 р. у ернівецькій обл. ст діонів з трибун ми н 1500 місць і більше було 31 (н один менше, ніж у 2005 р.), спортивних м йд нчиків - 904 (менше н 181), тенісних кортів 21 (більше н 11), футбольних полів - 259 (більше н 4), пл в льних 6 сейнів 10 (більше н 4), спортивних $з$ лів площею не менше $162 \mathrm{~m}^{2}-347$ (більше н 31), приміщень для фізкультурно-оздоровчих з нять - 240 (більше н 10).

к б чимо, розвиток соці льної інфр структури в ернівецькій обл. не можн сх p ктеризув ти однозн чно. ількісно не з зн ли сп ду і н віть збільшилися обсяги окремих видів послуг, особливо медичних, роздрібної й оптової торгівлі [10, с. 241]. роте скоротились обсяги спожив ння т кількість деяких видів спортивно-оздоровчих і культурних з кл дів. і особливості необхідно вр ховув ти в р зі створення об'єктів туристичної діяльності, продуктивного використ ння вільного т робочого ч су, з безпеченості з йнятості н селення.

ернівецьк обл. м $є$ б г то структурних компонентів рекре ційних ресурсів, $є$ регіоном б г топрофільного літнього, зимового, гірсько-спортивного, м сового пізн в льно-оздоровчого відпочинку. р й м є сприятливі клім тичні умови, т кож високий природно-рекре ційний потенці л, який бг то в чому визн ч є його 
соці льно-економічний профіль т прив бливість як для укр їнських туристів, т к і для іноземців. Г лом, з підр хунк ми укр їнських учених, з безпеченість природними рекре ційними ресурс ми н $1 \mathrm{kM}^{2}$ території т н одного жителя, відповідно, в 1,4 т 1,8 р $з$ вищі, ніж у середньому по кр їні [6, с. 330].

тже, у туристичному потенці лі кр ю - історичні т рхітектурні п м'ятки, релігійні споруди, п м’ятки культури т мистецтв, тр диційні н родні промисли т ремесл тощо. ернівецьк обл. - одн зі зн чних в кр їні, як м є б г ту рхітектурно-містобудівну сп дщину, різном нітну в етнічному, історичному, стилістичному, типологічному спект х. ут поєдн ні живописні гірські л ндш фти т м льовничі ліси передгір'я, численні річки й джерел лікув льних мінер льних вод, з ворожує кр с лісів і гірських лук, б г тих н мисливську ф уну, гриби т ягоди.

е можуть не прив блюв ти зр зки тр диційного н родного будівництв й ужиткового мистецтв , музеї під відкритим небом - живі носії своєрідності буковинського кр ю. ро це яскр во свідчить і н явність н терен х обл сті 314 об'єктів різних к тегорій природно-з повідного фонду, які 3 йм ють пон д 600,0 тис. г, бо більше 7 \% території ернівецької обл. цим пок зником кр й входить до чільної п'ятірки н йб ж ніших для відвідув ння обл стей кр їни. обл сті н лічується 112 об'єктів рхітектури й містобудув ння, які внесені до переліку з г льнон ціон льної сп дщини т пон д 800 місцевого зн чення. езиденція митрополитів уковини т лм ції (нині корпуси ернівецького н ціон льного університету імені рія едькович ) входить до списку об'єктів вітової сп дщини ьогодні дед лі переконливіше звучить тез про те, що “поетичне буковинське н ч ло" м є перетворитись у к тегорію економічну через розвиток туристичної індустрії.

1. ейдик . . екре ційні ресурси кр їни: н вч. посібник. $\quad . \quad$ льтпрес, 2009. 400 с.

2. утко . ., лєшугін . . р нспортн інфр структур як скл дов туристичного потенці лу кр їни // фективн економік . 2009. № 3 [ лектронний ресурс]. URL: http://www.economy.nayka.com.ua/?op=1\&z=62

3. рицку- ндрієщ . . рг ніз ційні т фін нсово-економічні спекти ктивіз ції сільського туризму // врійський н ук. вісник. 2010. ип. 70. 231-236.

4. юбіцев . . т лий розвиток туризму в кр їні як один із шляхів посилення конкурентних позицій н ринку міжн родного туризму // існик соці льно-екон. досліджень. 2008. ип. 33. . 393-397.

5. лійник . . еоретичні основи туризмології: н вч. посібник. . : ік - ентр, 2005. $316 \mathrm{c}$.

6. уденко . . еогр фія природно-ресурсного потенці лу кр їни: підручник у 3 ч. ернівці : ернівецький н ц. ун-т, 2010. 552 с.

7. $\quad$ м ль. т лий розвиток індустрії туризму: економіко-геогр фічний контекст // кр їн : геогр фічні проблеми ст лого розвитку: 4 т. . : $\quad$ брії, 2004. . 3. . 33-35.

8. т тистичний щорічник ернівецької обл. з 2016 рік. ернівці: $\quad$, 2017. 564 с.

9. теченко . ., езуглий . . уково-методичні основи еколого-рекре ційного р йонув ння // існик онецького ін-ту туристичного бізнесу. 2008. № 12. . 66-72.

10. опчієв . . успільно-геогр фічні дослідження: методологія, методи, методики: н вч. посібник. дес : стропринт, 2005. 632 с. 


\title{
REFERENCES
}

1. Bejdyk, O. O. (2009). Rekreatsiini resursy Ukrainy. Kyiv, 400 p. (in Ukrainian).

2. Butko, M. P., \& Alieshuhina, N.O. (2009). Transportna infrastruktura yak skladova turystychnoho potentsialu Ukrainy. Efektyvna ekonomika, 3. Retrieved from http://www.economy.nayka.com.ua/?op=1\&z=62 (in Ukrainian).

3. Hrytsku-Andriiesh, Yu. P. (2010). Orhanizatsiini ta finansovo-ekonomichni aspekty aktyvizatsii silskoho turyzmu. Tavriiskyi naukovyi visnyk, 70. Kherson: Ajlant, 231-236 (in Ukrainian).

4. Liubitseva, O. O. (2008). Stalyi rozvytok turyzmu v Ukraini yak odyn iz shliakhiv posylennia konkurentnykh pozytsii na rynku mizhnarodnoho turyzmu. Visnyk sotsialnoekon. doslidzhen, 33. Odesa: ODEU, 393-397 (in Ukrainian).

5. Oliinyk, Ya. B. (2005). Teoretychni osnovy turyzmolohii. Kyiv: Nika-Tsentr, 316 p. (in Ukrainian).

6. Rudenko, V. P. (2010). Heohrafiia pryrodno-resursnoho potentsialu Ukrainy. Chernivtsi: Chernivetskyi nats. un-t, 552 p. (in Ukrainian).

7. Smal, I. (2004). Stalyi rozvytok industrii turyzmu: ekonomiko-heohrafichnyi kontekst. Ukraina: heohrafichni problemy staloho rozvytku, 3 (Vols. 1-4). Kyiv: VHL Obrii, 33-35 (in Ukrainian).

8. Statystychnyi shchorichnyk Chernivetskoi obl. za 2016 rik (2017). Chernivtsi: DKSTU, 564 p. (in Ukrainian).

9. Stechenko, D. M., \& Bezuhlyi, I. V. (2008). Naukovo-metodychni osnovy ekolohorekreatsiinoho raionuvannia. Visnyk Donetskoho in-tu turystychnoho biznesu, 12, 66-72 (in Ukrainian).

10. Topchiiev, O. H. (2005). Suspilno-heohrafichni doslidzhennia: metodolohiia, metody, metodyky. Odesa: Astroprynt, 632 p. (in Ukrainian).

m ття: н дійшл до ред кції 20.12.2017

доопр иьов н 25.01.2018

прийнят до друку 06.02.2018

\section{CONDITIONS AND RESOURCES OF FORMATION AND DEVELOPMENT \\ OF TOURISM ACTIVITY IN CHERNIVTSI REGION AS A CROSS-BORDER REGION: SOCIAL-GEOGRAPHICAL ASSESSMENT AND DIAGNOSTICS}

\author{
Veronika Hrytsku \\ Yuriy Fedkovych Chernivtsi National University, \\ M. Kocubynskiy St., 2, UA-58012 Chernivtsi, Ukraine, \\ e-mail:veronika-hrytsku@ukr.net
}

The article identifies the main conditions and resources for the formation and development of tourist activity in Chernivtsi region as a cross-border region. Due to its spatial predisposition, particular attention is paid to socio-geographical assessment and diagnosis of favourable and unfavourable factors, as well as those that determine the functional-sectoral structure and territorial organization of tourism activity. As a group of them, a socio-geographical position (cross-border provision,); settlement network, demo-reproduction situation and employment of the population; level of economic development; the potential of tourism services. In terms of population density, Chernivtsi Oblast is 
Умови та ресурси формування й розвитку туристичної діяльності ...

fourth in Ukraine and this figure is higher by $38.1 \%$ than the average in Ukraine. The most populated are plain and foothill areas. The housing stock of the region is sufficient and corresponds to the national level $-22.1 \mathrm{~m}^{2} /$ per inhabitant, better the living conditions are provided by the villagers $\left(23.4 \mathrm{~m}^{2} /\right.$ person$)$ than urban $\left(20.2 \mathrm{~m}^{2} /\right.$ per person). The oblast has a considerable length and extensive network of communication paths. This contributes to the intensity of transportation, commodity exchange, the provision of the consumer market, increasing the opportunities for the transfer of tourists. However, in recent years, road construction has been at a much slower pace than in previous periods. The work of educational, medical, cultural and artistic institutions plays an important role in tourism employment. The article provides a detailed analysis of the functioning of the social infrastructure of the region. Bukovina as a cross-border region has many structural components of recreational resources; it is a region of multifaceted summer, winter, mountain-sports, mass cognitive-recreational rest. The use of statistical methods and quantitative indicators allowed to identify the features and specifics of tourism activity, to substantiate the prospects for improving the organization, structure and sustainable development.

Key words: tourism activity, conditions, resources, population, employment, sustainable development, prospects. 